Karmawibangga : Historical Studies Journal, Vol: 01, No: 01, 2019: 43-52

ISSN:- E-ISSN:

htpps://journal.upy.ac.id/index.php/karmawibangga

\title{
BELAJAR TOLERANSI DAN KEBHINEKAAN MELALUI SITUS CANDI BOGANG
}

Oleh : Teguh Setiyono,

Guru Seajarah SMAN 1 Wonosobo

tegesaja13@gmail.com

\begin{abstract}
Abstrak
Tujuan dari penulisan ini adalah untuk mengungkap nilai-nilai toleransi dan kebhinekaan dari situs candi Bogang pada masyarakat Wonosobo agar di kalangan generasi muda dan terpelajar sebagai agent of change tidak terjebak dalam konflik yang dapat menimbulkan perpecahan bangsa.

Penulisan ini menggunakan metode kualitatif, yakni untuk meniliti subuah fenomena sosial. Dimana dalam memecahkan kasus-kasus sosial terkadang tidak bisa dengan tolak ukur atau temuan melalui alat prosedur statistik atau alat kuantifikasi lainnya. Dengan metode kualitatif didapatkan data melalui tulisan, wawancara, foto ataupun video. Lalu di analisis dan interpretasikan menjadi sebuah tulisan yang sistematis

Hasil dan pembahasan solusi supaya generasi muda tidak terjebak dalam permasalahan yang mengancam keutuhan bangsa yakni dengan mengajak generasi muda untuk belajar sejarah. Melalui kajian situs peninggalan sejarah arca Bogang di Wonosobo, dapat mempersatukan kebhinekaan masyarakat pada masa lampau.
\end{abstract}

Kata kunci: Toleransi dan Kebhinekaan, candi Bogang, Komunitas

\begin{abstract}
The purpose of this paper is to reveal the values of tolerance and diversity of the Bogang temple site in the Wonosobo community so that the young and educated generation as agents of change are not trapped in conflicts that can cause national disunity.

This writing uses qualitative methods, namely to assess the subset of social phenomena. Where in solving social cases can sometimes not be with benchmarks or findings through statistical procedure tools or other quantification tools. With qualitative methods data is obtained through writing, interviews, photos or videos. Then analyzed and interpreted into a systematic writing.

Results and discussion of solutions so that the younger generation is not trapped in problems that threaten the integrity of the nation by inviting the younger generation to study history. Through the study of the Bogang statues heritage site in Wonosobo, it can unite the diversity of society in the past.
\end{abstract}

Keyword : Tolerance and Kebhinekaan, Bogang temple, Community 


\section{PENDAHULUAN}

Globalisasi telah menyebabkan bergesernya nilai-nilai. Banyak diantara kita, utamanya generasi muda sudah tidak lagi atau kurang mengenal nilai-nilai budaya bangsa. Padahal nilai-nilai tersebut diperlukan untuk memperkokoh moral dan identitas, meningkatkan daya saing, serta menguasai ilmu pengetahuan, teknologi dan seni (Suminto, tt: 1). Begitu juga dengan hingar-bingarnya politik di Indonesia sekarang ini. Ketika generasi muda banyak dipertontonkan hal-hal yang kurang terpuji, baik tersebarnya hoax secara massif, kekerasan berbau sara, isu promordialisme yang dibalut sentiment politik dan semua hal lainnya. Dengan keadaan tersebut semangat kebhinekaan dan toleransi yang sudah dirumuskan para pendiri bangsa dan sudah menjadi semboyan bangsa Indonesia sepertinya sepertinya mulai terlupakan. Tergantikan dengan kepentingan sesaat.

Namun sebagai generasi muda tidak boleh terjebak rasa pesimistis dengan keadaan tersebut diatas, sebagai generasi muda harus benar-benar bisa menjadi agent of change. Masih banyak hal-hal positif yang bisa kita contoh, kita pelajari dan kita lakukan. Salah satu yang bisa dilakukan adalah dengan belajar pada sejarah bangsa kita. Karena dengan belajar sejarah "Insyallah" kita akan menjadi orang yang lebih bijak dalam menyikapi segala sesuatu.

Contoh media untuk pembelajaran sejarah adalah melalui cagar budaya, karena Cagar budaya adalah jejak sejarah tangible yang bisa kita pelajari sekarang. Cagar budaya suatu bangsa adalah ciptaan bangsa pada masa lalu yang memiliki arti penting bagi kebudayaan suatu bangsa, khususnya untuk memupuk rasa kebanggan nasional serta memperkokoh jatidiri suatu bangsa. Kekayaan dan keanekaragaman Cagar Budaya dapat dimanfaatkan sebagai sarana pendidikan, penelitian dan wisata. Begitu juga sebagai identitas jatidiri suatu bangsa yang adiluhung. Adapun dalam makalah ini akan dibahas bagaimana penyerapan nilainilai sebuah Cagar Budaya Arca Bogang untuk menumbuhkan semangat kebinekaan bagi generasi muda.

METODE

Dalam menulis makalah ilmiah ini menggunakan metode kualitatif. Metode kualitatif adalah yang paling tepat untuk meniliti subuah fenomena sosial (Ahmadi, Rulam. 2014: 10). Dimana dalam memecahkan kasus-kasus sosial terkadang tidak bisa dengan tolak ukur atau temuan melalui alat alat prosedur statistik atau alat alat kuantifikasi lainnya. Dengan metode kualitatif didapatkan data melalui tulisan, wawancara, foto ataupun video. Lalu di analisis dan interpretasikan menjadi sebuah tulisan yang sistematis (Ahmadi, Rulam. 2014: 10).

\section{HASIL DAN PEMBAHASAN \\ a. Generasi Muda, Toleransi dan Kebhinekaan}

Indonesia yang terletak dijalur persimpangan jalur perdagangan dunia menyebabkan pertemuan berbagai budaya dunia hingga menciptakan corak kebudayaan baru yang unik dan menarik. Cina yang membawa pengaruh agama Kong $\mathrm{Hu} \mathrm{Chu}$, India membawa pengaruh Hindu-Budha, Persia membawa pengaruh Islam dan Eropa membawa Kristen semua dapat berkembang dan diterima oleh masyarakat Nusantara. Namun pengaruh asing tersebut tidak diterima begitu saja, semua sudah melalui proses adaptasi dengan budaya lokal (Yadav, Jai Singh. 2002: 5). Dengan fakta sejarah tersebut diatas slogan Bhineka Tunggal Ika sebenarnya sudah terkonsep jauh sebelum Indonesia Merdeka. Sehingga toleransi 
merupakan hal yang sudah mendarah daging di Nusantara. Namun seiring dengan berkembangnya jaman yang semakin modern, justru banyak sekali kelompok-kelompok yang berusaha mengusik ketenangan kehidupan yang harmonis di Nusantara. Dan yang mengkwatirkan adalah ketika generasi muda menjadi sasaran untuk menyebarkan hal tersebut. Dengan keadaan tersebut, pada saat ini sangat dibutuhkan pembelajaran sejarah yang berhubungan dengan nilai-nilai luhur kebangsaan yang menjujung tinggi kemanusiaan, toleransi dan kebhinekaan.

Pada masa yang serba modern dan instant ini, generasi muda harus selalu tampil prima untuk menjadi garda terdepan bangsa Indonesia ini. Sehingga bekal dari dalam diri sendiri yang berupa karakter dan watak yang positif harus senantiasa dipupuk dan dibangun. Baik secara material maupun non material. Apalagi sekarang ini ketika berbagai pengaruh dari bangsa asing terus menerus merangsek masuk ke Nusantara tercinta ini. Di era medsos ini, semua serba cepat dan instan, informasi apapun begitu mudah didapatkan. Namun semua itu tidak menjamin semua itu benar, kita harus benar-benar bijak dalam menerima setiap informasi apapun.

Dengan kondisi tersebut diatas, tentunya membawa banyak sekali perubahan dan pengaruh positif maupun negatif pada generasi muda. Hoaks adalah salah satu contoh pengaruh negatif, inilah hal yang paling berbahaya, apalagi sekarang ketika sudah menyasar sentiment sara, primordialisme dan perbedaanperbedaan lainnya yang mengancam persatuan dan kesatuan NKRI yang berslogan Bhineka Tunggal Ika yang mempunyai arti berbeda-beda tetap satu juga. Sebenarnya frasa 'Bhinneka Tunggal
Ika' telah tercipta jauh sebelum Indonesia merdeka. 'Bhinneka Tunggal Ika' adalah sebuah frasa yang terdapat dalam Kakawin Sutasoma.

Kakawin sendiri berarti syair dengan bahasa Jawa kuno. Kakawin Sutasoma merupakan karangan $\mathrm{Mpu}$ Tantular yang dituliskan menggunakan bahasa Jawa kuno. Diketahui, Kakawin Sutasoma dikarang pada abad ke-14 (Hendarman Supanji. 2012: 6). Hal ini menunjukkan persatuan dan kesatuan yang terjadi di wilayah Indonesia, dengan keberagaman penduduk Indonesia yang terdiri dari bermacam-macam suku, bahasa daerah, ras, agama, dan kepercayaan, lantas tidak membuat Indonesia menjadi terpecah-belah. Melalui semboyan ini, Indonesia bisa dipersatukan dan semua keberagaman tersebut menjadi satu bagian dari Negara Kesatuan Republik Indonesia (NKRI). Modernitas memang tidak terbendung dan menjelma menjadi kebutuhan pokok generasi muda, kita tetap membutuhkan banyak nilai-nilai luhur untuk mengisi jiwa kita.Supaya kita tidak menjadi mahkluk yang hanya bersifat materialistis, namun tetap menjadi manjadi generasi muda yang peka, humanis, bijak dan menghargai perbedaan. Itulah Generasi Muda Indonesia

Salah satu cara untuk mencari hal tersebut adalah dengan belajar sejarah. Karena dengan belajar sejarah kita akan terbiasa menjadi generasi literasi yang kritis terhadap berbagai fenomena yang terjadi pada umat manusia. Kita akan mempelajari berbagai macam budaya, agama dan suku bangsa yang semuanya berbeda-beda. Nusantara bisa menjadi kuat karena adanya perbedaan dari Sabang hingga Merauke. Salah satu fenomena dan peninggalan sejarah yang bisa menjadi pembelajaran bagi generasi muda dan 
khususnya di Wonosobo adalah di situs Cagar Budaya Arca Bogang.

\section{b. Tentang Situs Candi Bogang Geografis}

Secara umum Situs Candi Bogang berada di Desa Bogang, Kecamatan Selomerto, Kabupaten Wonosobo.Yang mana Wonosobo merupakan salah satu kabupaten di Jawa Tengah dengan ketinggian \pm 608 . 398 meter di atas permukaan air laut. Untuk lokasi situs berada di posisi $3^{\circ} 14$ '4" Bujur Timur dan 7'35'00" Litang Selatan, Meridian Jakarta (Djoko Dwiyanto, 1982: 440). Daerah ini termasuk daerah tropis yang memiliki iklim yang dingin. Lokasi Kabupaten Wonosobo diapit Pegunungan Dieng di Utara dan Gunung Sindoro serta Sumbing di Timur (Dinas Pariwisata Wonosobo, 2009: 2). Dengan lokasi yang cukup tinggi tersebut, Kabupaten Wonosobo mempunyai banyak keunikan yang tidak dipunyai oleh kabupaten lain. Baik secara budaya, kuliner maupun kesejarahan. Begitu juga dengan tinggalan arkeologinya.

\section{c. Historis Situs Candi Bogang}

Situs candi Bogang ini diperkirakan dibangun pada abad 7-9 Masehi. Masuknya pengaruh agama Hindu-Budha telah mengubah sistem religi. Agama juga digunakan sebagai pegangan moral dan etika hidup bernegara. Pada masa-masa kejayaan pengaruh Hindu-Budha di Jawa Tengah atau yang lebih dikenal dengan sebutan masa klasik. Masa Klasik adalah periodesasi yang digunakan untuk menandai kesenian yang berkembang pada masa Indonesia Kuno (Azzah, Zaimul, 2009: 40). Ketika agama Hindu-Budha berjalan beriringan dan harmonis sehingga wajar saja ketika dua agama ini berkembang pesat di Jawa Tengah. Adapun daerah Wonosobo diperkirakan pernah menjadi kawasan penting pada masa itu. Hal tersebut diperkuat dengan isi prasasti Mantyasih I berangka $829 \mathrm{Caka}$, yang mana kawanan Wonosobo dinamakan Pereng Susundara dan Sumving. Disebutkan bahwa hutan dan sawah disekitar gunung tersebut (Sindoro dan Sumbing) sebagai daerah Sima. Adapun isi dari prasasti tersebut adalah:"... savah kanayakan muang alasanya I susundara I vukir sumving kapua patapan sinusuk sima kapatihana..." yang mempunyai arti...sawah milik (para) Nayaka, serta hutannya di gunung Sindoro, Gunung Sumbing semuanya wilayah Patapan, dibatasi menjadi Sima atau daerah perdikan bagi para Patih..." (J.G Casparis. 1956: 64). Dengan adanya keterangan diatas sudah jelaslah bahwa Wonosobo yang berada di lereng kedua gunung yang disebutkan pada prasasti Mantyasih I merupakan daerah yang penting pada masa Mataram Kuno. Sehingga bisa dimaklumi apabila banyak tinggalan arkeologi di kabupaten Wonosobo. Baik berupa arca, lingga-yoni, komponen candi, pecahan gerabah kuno dan lainnya. Diantara peninggalanpeninggalan tersebut adalah Situs candi Bogang.

Untuk situs candi Bogang, meski menyandang nama candi namun tidak seperti bayangan sebuah candi pada umumnya. Karena sebenarnya yang berada dilokasi situs adalah satu Arca Dyani-Budha tanpa kepala yang terbilang cukup besar dan satu arca Dyani Bodhisatva yang juga tanpa kepala (Wawancara dengan Bapak Yudi Hartono, Arkeolog dan Kurator Balai Koservasi Borobudur). Mengapa situs arca tersebut dikatakan sebuah candi? kemungkinan penyebutan candi adalah kebiasaan masyarakat Jawa yang memberikan nama 
pada setiap tumpukan batu kuno yang banyak disuatu tempat. Dalam bahasa sansekerta sendiri, candi yang berasal dari kata candika mempunyai arti Dewi Kematian atau Dewi Durga (Dinbudpar, 2011: 7).

Situs candi Bogang ini pertama kali ditemukan pada tahun 1982 ketika para pekerja akan membuat sebuah pondasi bangunan. Lalu ditindak lanjuti oleh tim Suaka Peninggalan Sejarah dan Purbakala Jawa Tengah dan Jurusan Arkeologi Fakultas Sastra UGM hingga ditemukan fragmen arca berupa kepala arca Budha, dua badan arca dan fragmenfragmen lainnya, diantaranya 4 buah batu umpak bulat besar (Djoko Dwiyanto, 1982: 443). Hingga pada tahun 2015 oleh tim BPCB Jawa Tengah dan dilakukan penggalian ulang di lokasi situs. Satu arca Dyani Budha yang semula separuh tubuhnya masih di dalam tanah bisa diangkat kembali dan disandingkan dengan arca Dhyani Bodhisatwa Wajrapani yang sudah diangkat dan dipajang dilokasi sejak ditemukan tahun 1982.

Diperkirakan diarea situs pada masa lalu terdapat semacam pendopo. Hal ini dapat dilihat adanya tumpukan batur yang terbuat dari batu andesit, batu pasir dan batu bata merah dengan denah persegi empat. Begitu dengan adanya 4 umpak cukup besar yang berada di lokasi. Selain fragmen arca maupun temuan lepas lainya, dilokasi juga ditemukan 2 lempengan logam yang terbuat dari timah putih dan emas. Adapun yang emas bertuliskan prasasti dengan huruf Jawa Kuno dan berbahasa Sanskerta (Djoko Dwiyanto.1982: 444). Menurut Djoko Dwiyanto dalam Buku Laporannya menyebutkan bahwa Candi Bogang lebih tua masanya dari bangunan candi Mendut.

\section{d. Tentang Kepala Arca yang Terpenggal}

Dilokasi situs terdapat dua arca besar. Uniknya dua-duanya dalam keadaaan terpenggal. Berbeda ketika kita ke candi Mendut atau Borobudur yang mana di sana terdapat banyak arca Budha yang masih lengkap dan utuh. Namun apabila kita mengunjungi candi Plaosan di Klaten, kita juga akan menemukan acra Budha yang tidak ada kepalanya. Tidak hanya satu, semuanya berjumlah 22 arca yang terpenggal kepalanya (Wawancara dengan Bapak. Yudi Hartono, Arkeolog dan Kurator Balai Koservasi Borobudur). Menurut Sugeng Widodo, Kepala Kelompok Kerja BP3 Jateng, dalam Kompas 11 Maret 2011 mengatakan, sebagian besar kepala arca hilang dikarenakan terjadi pencurian terhadap benda berharga tersebut. Menurut catatan BP3 Jateng, dari tahun 1975 sampai tahun 2000 terdapat 86 kali kasus pencurian yang mengakibatkan hilangnya 133 benda purbakala yang hilang.

Begitu juga dengan hasil wawancara dengan bapak Yudi Hartono, di Balai Konservasi Borobudur mengatakan terjadi juga pemenggalan beberapa arca di candi Borobudur. Pemenggalan kepala tidak hanya sematasemata karena unsur pencurian, karena kejadian tersebut sudah dimulai pada abad 15, yaitu ketika VOC sudah mempunyai pengaruh kuat di Jawa. Dimungkinkan kepala arca Budha ini banyak dijadikan oleh-oleh dan suvenir oleh para Pejabat di jaman Hindia-Belanda. Kemungkinan ini juga yang terjadi juga pada arca Budha di situs Candi Bogang Wonosobo.

Adapun dua arca yang ada di situs Bogang adalah:

1) Arca Dhyani-Budha Wairocana Arca Budha ini memiliki tubuh yang besar, apabila kepalanya utuh 
diperkirkan tingginya sekitar tiga meter. Arca ini terbuat dari batu pasir yang rapuh dan berwarna coklat. Kepala terpenggal dan tangan sudah patah. Menurut data yang dibuat oleh BPCB Jawa Tengah, arca ini adalah Dyani Budha. Arca ini mempunyai sikap tangan dharmacakramudra yaitu tangan melingkar memutar roda dharma, arca ini posisinya di pusat atau Zenith (Soekmono. 2002: 95). Dalam ajaran Budha, Dyani Budha adalah seseorang yang telah mendapatkan pengetahuan keagamaan dan terbebas dari lingkaran karma. Mengenakan jubah tanpa jahitan yang terdiri dari tiga lembar kain, atau disebut juga Trisiwara. Dyani Budha berjumlah lima orang dengan posisi yang berbeda (Kemendikbud Balai Pelestarian Jawa Tengah. 2018: 13) yaitu:

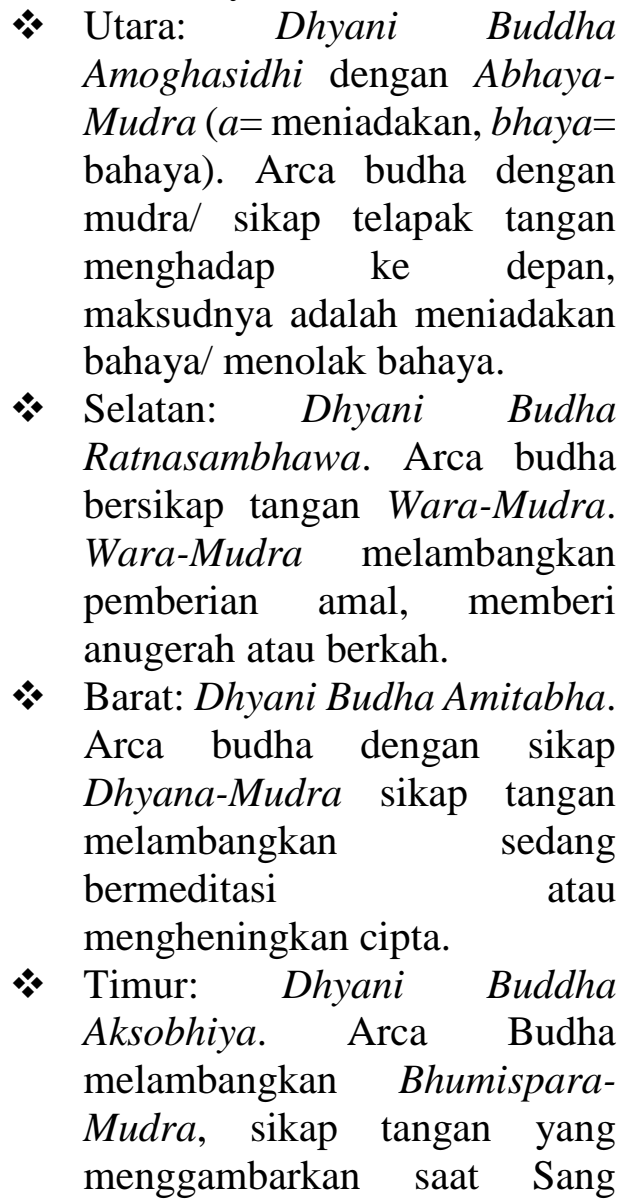

Budha memanggil dewi bumi, sebagai saksi ketika ia menangkis semua serangan iblis (mara).

* Zenith/ pusat: Dhyani Budha Wairocana. Arca Budha dengan sikap Dharma Cakra-Mudra melambangkan gerak memutar roda dharma. Di Candi Borobudur, Mudra ini digambarkan dengan sikap tangan yang disebut WitarkaMudra (Harry Setyawan dkk. 2017 : 12).

2) Arca Bodhisatwa Wajrapani

Arca yang kedua lebih kecil, dan diindikasikan sebgai arca Bodhisatwa Wajrapani. Wajrapani adalah salah satu diantara tiga dewa pelindung yang mengelilingi Budha, yaitu Manjusri, Awalokiteswara dan Wajprani itu sendiri (Djoko Dwiyanto.1982: 444). Arca ini memiliki ketinggian kurang lebih 2,5 meter. Sama dengan arca satunya, arca Bodhisatwa ini dalam keadaan terpenggal. Namun pahatan yang mencirikan arca ini Bodhisatwa masih sangat terlihat. Dalam ajaran Budha, Arti dari Bodhisatwa atau Bodhysatvaa adalah tokoh yang mendedikasikan dirinya demi kebahagiaan lainnya di alam semesta yang memiliki kebajikan luar biasa dan sudah dapat mencapai nirwana.Namun Bodhisatwa memilih tinggal didunia dan menolong umat manusia. Dalam melaksanakan tugasnya Bodhisatwa diperkenankan mengenakan pakaian layaknya bangsawan dan memiliki kekuasaan (Tim BPCB Jateng. $2018: 24$ )

3) Kondisi Kepala arca

Dilokasi situs, kedua-duanya sudah tidak mempunyai kepala. Setelah melalui penelusuran, ternyata satu kepala dari arca Dhyani Budha tersimpan di museum Karmawingga Borobudur. 
Adapun alasan penyimpanan kepala di Musseum Karmawingga Borobudur adalah alasan keamanan.

Beberapa ciri Kepala Budha Situs Bogang yang tersimpan di museum Karmawibangga adalah:

* Pada ujung kepala, rambut Sang Budha keriting dan selalu searah jarum jam dan disanggul ushnisa.

* Pada dahinya terdapat tonjolan kecil yang disebut urna.

* Arca Budha memiliki telinga yang panjang sebagai gambaran kalau Budha itu Maha Mendengar.

* Mata Budha digambarkan setengah terpejam karena melambangkan orang yang melakukan yoga yang bertujuan untuk membantu konsentrasi. Setelah memejamkan mata kemudian perhatian diarahkan ke ujung hidung untuk bisa membantu konsentrasi (Harry Setyawan dkk. 2017 : 3).

\section{e. Nilai-nilai Kebhinekaan di Situs Arca Bogang}

Dengan berbagai data diatas, situs Candi Bogang jelaslah mempunyai kajian sejarah yang tinggi dan mempunyai nilainilai yang relevan untuk pendidikan generasi muda masa kini. Karena keadaan masa kini adalah kelanjutan dari masa lampau. Masa kini adalah benih-benih pertumbuhan masa depan. Pelacakan masa lampau dapat ditelusuri dari jejak sejarah. Karena jejak sejarah merupakan fakta dan dan penanda rekaman sejarah. Baik berupa artifact, mentifact, maupun socifact (Suhartono, Yudi. 2017: 12). Generasi muda sekarang tidak boleh melupakan hal ini.

$\begin{array}{rrr}\text { Peninggalan } & \text { sejarah } & \text { dapat } \\ \text { mencerminkan } & \text { kehidupan } & \text { dan }\end{array}$

penghidupan di masyarakat dengan aspeknya, baik sosial budaya, politik, ekonomi maupun agama. Jejak sejarah sebagai sumberdaya budaya yang bersifat fisik (tangible) dapat berupa bangunan, monument, lukisan dan sebagainya. Jejak sejarah ini merupakan kekayaan yang tidak ternilai dan sekaligus sebagai identitas atau kepribadian budaya yang pada gilirannya dapat mewujudkan sikap mantap dalam mempertahankan dan memupuk karakter bangsa sehingga bangsa Indonesia mampu eksis dalam era pengaruh global tanpa perlu kehilangan identitas kepribadian bangsanya (Taufik Abdullah, 2001 : 50). Sehingga sebuah jejak sejarahyang bercorak agama dan budaya manapun merupakan warisan budaya bangsa yang harus dilestarikan untuk dapat diwariskan kepada generasi yang akan datang. Banyak sekali hal yang bisa dipelajari dengan melestarikan cagar budaya itu sendiri. Sejarah selalu menjadi inspirasi di masa depan. Oleh karena itu sejarah adalah bagian terpenting dalam memotivasi kemajuan suatu bangsa. Tepat jika beliau Bung Karno mengatakan "Jangan Sekali-kali Melupakan Sejarah".

Bagi generasi muda di Wonosobo, salah satu cagar budaya yang bisa untuk pembelajaran dan merenungkan tentang konsep kebhinekaan yang digagas bung Karno dan memang kita butuhkan saat ini adalah Situs Arca Bogang. Mengapa harus arca Bogang? Jawaban dari pertanyaan ini adalah karena Arca Bogang mempunyai keunikan dan kekhususan sendiri yang berhubungan dengan keberagaman. Dimana lingkungan dari arca Bogang yang bercorak Budha sangat didominasi oleh temuan yang keseluruhan bercorak Hindu. Baik itu situs Tumenggungan, Situs Arca Wonolelo, Yoni Binangun, Situs Candi Bongkotan, Candi Watumalang, Situs 
Candirejo, Yoni Bangsri dan tentunya candi Dieng itu sendiri. Belum lagi temuan lingga-yoni yang banyak disawah, kebun dan pemakaman tua. Semua temuan yang bercorak Hindu ini tentunya selaras dengan prasati Mantyasih yang menyebutkan bahwa kawasan SindoroSumbing adalah sebuah Sima yang diberikan Rakai Pikatan dari Dinasti Syailendra pada Patihnya. Tentunya dengan lingkungan seperti ini, adanya sebuah bangunan minoritas di tengah lingkungan yang mayoritas memunculkan buah pemikiran bahwa pada abad VII -XV $M$ di wilayah tersebut sudah muncul toleransi beragama yang kuat. Hal tersebut mengingatkan pada kompleks candi Prambanan, yang terdiri dari gugusan candi Hindu dan Budha. Diantaranya yaitu candi Prambanan, candi Lumbung, Candi Bubrah dan candi Sewu yang bercorak Budha. Kompleks candi dibangun pada masa pemerintahan Rakai Pikatan yang beragama Hindu dan Permaisurinya Pramodhawardani yang beragama Budha (Soekmono. 2002: 95).

Apabila hal tersebut diatas benar apa adanya bahwa arca Bogang merupakan representasi dari harmoni keberbedaaan dimasa lalu , tentunya kita sebagai generasi muda di kabupaten Wonosobo merasa bangga, bahwa kebhinekaan dan harmoni antar umat beragama sudah muncul di Wonosobo dari masa lampau. Sebagai generasi muda yang hidup pada masa kini, sudah menjadi kewajiban kita untuk melestarikan cagar budaya peninggalan nenek moyang kita.

Apalagi semua hal tersebut diatas sesuai dengan predikat Wonosobo sebagai kota ramah HAM yang mana toleransi termasuk didalamnya. Sekiranya tidak berlebihan apabila Situs Candi Bogang bisa dijadikan referensi masyarakat Wonosobo apabila toleransi terhadap perbedaan sudah terjadi dari masa lampau, dari masa kejayaan Mataram Kuno. Bahkan pada tanggal 13 November 2018 yang lalu, Wonosobo sebagai tuan rumah dari acara Festival Hak Asasi Manusia (HAM) Mereka datang dari berbagai kota di Indonesia bahkan perwakilan dari luar negeri. Acara diikuti oleh lintas oraganisasi dan lintas agama.

Nilai nilai kebinekaan yang bisa kita ambil dari situs Arca Bogang adalah:

- Toleransi, dibuktikan dengan lingkungan arca Bogang yang beragama Hindu. Dapat dimungkinkan pada masa lalu sudah ada toleransi yang kuat di lokasi situs. Hal ini sebagai pembelajaran bahwa bangsa Indonesia adalah bangsa toleran.

* Gotong royong, tentunya dalam pembuatan kompleks situs, membutuhkan tenaga yang banyak dan gotong royong memang sudah menjadi ciri di seluruh tanah Nusantara ini. Tentunya melibatkan semua unsur dimasyarakat dengan latar belakang yang berbeda-beda.

- Ketaatan Beragama, situs Arca Bogang boleh dibilang sebuah simbol ketaatan beragama yang kuat. Artinya ketika golongan agama minoritas berani membuat sebuah bangunan agama di tengah lingkungan agama mayoritas. Hal ini memcerminkan bahwa ketaatan beribadah adalah nomor satu, sehingga selalu siap dengan resikonya.

* Bijaksana, dalam hal ini bisa disematkan pada pemangku kekuasaan. Yang mana bahwa arca bogang dibangun disebuah wilayah Dinasti Sanjaya yang tentunya beragama Hindu. Hal ini apabila tidak ada kepemimpinan yang bijak, pasti 
akan ada pelarangan dalam hal pembangunan.

\section{KESIMPULAN}

Warisan sejarah (historical heritage) adalah bukti yang ditinggalkan manusia masa lampau yang dapat menggambarkan, menjelaskan serta memahami tingkah laku dan interaksi manusia dengan lingkungannya. Oleh karena itu dapat diketahui bahwa suatu warisan sejarah tidak dapat dipisahkan dari sistem budaya dan alam yang melatar belakanginya.

Situs Candi Bogang adalah mahakarya nenek moyang yang patut untuk dilindungi, dilestarikan, diberdayakan dan dimanfaatkan sesuai dengan UU Cagar Budaya no 11 tahun 2010. Pada masa lalu situs Bogang ini diperkirakan sebuah tempat peribadatan agama Budha Mahayana dengan dua arca Dyani Budha dan arca Bodhisatva Wajrapani dengan tempat semacam pendopo, hal ini dibuktikan adanya batur yang terbuat dari batu andhesit, batu pasir dan batu bata merah. Juga adanya umpak bulat besar yang berjumlah empat buah. Keunikan utama yang menonjol dari situs Bogang adalah situs tempat peribadatan agama Budha yang berada di lingkungan mayoritas dengan budaya Hindu.

Dengan mempelajari tentang nilainilai luhur berbagai peninggalan hasil mahakarya nenek moyang pada umumnya, dan pada khususnya dalam makalah ini adalah situs arca Bogang adalah salah satu hal penting dalam pembinaan karakter yang positif bagi generasi muda ditengah arus globalisasi dan informasi yang begitu cepat menggerus nilai-nilai luhur budaya bangsa. Karena melalui sejarah akan karakter generasi muda yang baik. Yang bisa memahami arti kebinekaan. Kelebihan dan kekuatan sesorang apabila tidak disertai karakter yang baik, akan menjadi kekurangan dan kelemahan yang berdampak dua kali lipat lebih besar dari pada kelebihan dan kekuatan orang itu. Dengan kehidupan yang berbeda-beda, di situlah letak keindahan.Tidak hanya slogan, tapi semangat kebinekaan harus kita lakukan.

Hal ini menjadi tugas bersama.Tidak hanya generasi muda saja. Namun dari semua unsur. Baik dinas terkait, komunitas sejarah, organisasi masyarakat, civitas akademika, biro wisata dan unsureunsur lainya. Sehingga semangat kebinekaan tersebut akan memunculkan sinergitas yang positif dan menghasilkan yang terbaik.

\section{DAFTAR PUSTAKA}

Ahmadi, Rulam. 2014. Metodolgi Penelitian Kualitatif. Ar-Ruzz Media. Jakarta

Asa, Kusnin; Sukendar, Haris; Suhadi, Machdi. 2008. Sejarah Wonosobo Edisi Prasejarah Hindu Budha Islam. Wonosobo: Dinas

Pariwisata dan Kebudayaan Kabupaten Wonosobo

Azzah, Zaimul ,2009. Dewa-Dewi Masa Klasik Jawa Tengah. Prambanan:

Balai Pelestarian Peninggalan

Purbakal Jawa Tengah

Booklet Dinas Pariwisata Wonosobo, 2009

Buku Inventaris Cagar Budaya Wonosobo, hal 7, Tahun 2011

Djoko Dwiyanto.1982. Laporan Pendahuluan Pengamanan Situs Candi Bogang, SPS dan P Jawa Tengah. (tidak diterbitkan)

-------. 2007. Belajar Sejarah yang Menyenangkan. FIB Universitas Gajah Mada

Harry Setyawan dkk. 2017. Jurnal Konservasi Cagar Budaya Borobudur: Kajian Pencocokan Kepala Arca Budha Candi 
Borobudur Tahap II. Balai Konservasi Borobudur. Magelang

Soekmono. 1985. Pengantar Sejarah Kebudayaan Jilid II. Yogyakarta. Kanisius

Soenarno. 2002. Kekuatan Komunitas Sebagai Pilar Pembangunan Nasional. Jakarta

Suhartono, Yudi dkk.2017.Borobudur Pedia.Balai Koservasi Borobudur. Magelang

Suminto. A. Suyuti. -. Cagar Budaya dan Pendidikan. Sebuah Makalah
Taufik Abdullah, 2001, Nasionalisme dan Sejarah. Satya Historika. Bandung Tim Kemendikbud

BPCB Jateng 2018. Peninggalan Arkeologi di Pereng Wukir Susundara-Sumving. Balai Pelestarian Cagar Budaya Jawa Tengah

Yadav, Jai Singh. 2002 "Pengaruh Budaya India pada Candi di Indonesia, dalam candi Sebagai Warisan Seni dan Budaya Indonesia. Yayasan Cempaka Yogyakarta 